\title{
（205）地震被害想定調査の比較検討および今後の調查への提案
}

$\begin{array}{cr}\text { 東京大学生産技術研究所 } & \begin{array}{r}\text { 後藤 } \\ \text { 寛子 } \\ \text { 同上 } \\ \text { 同上 }\end{array} \\ \text { 山崎 } & \text { 文雄 } \\ & \text { 恒雄 }\end{array}$

1.はじめに

国および多くの地方自治体では，地震に対する地域防災計画を策定するための前提を得るために，さまざま な地震被害想定調査を実施している。しかし、複数機関が同地域において予測した想定結果が大幅に異なって いることが指摘されたり、阪神・淡路大震災後、神戸市で震度 5 を想定して防災計画を策定していたことが注 目されるなど、数多くの問題点があると考えられる。今後も多くの自治体で被害想定調查への着手や見直しが 考えられることから、現在までの調査の問題点をまとめておくことは重要である。

本報告では，現在まで実施された被害想定調査から調查内容の問題点と今後の課題をまとめた。また、地域 防災計画と被害想定項目の関係、想定結果の利用状況から、被害想定調査の利用面からの問題点をまとめた. 以上から、今後の被害想定調查の進め方を提案する.

\section{2. 地震被害想定調查の現状}

被害想定調查とは，その地域で発生する可能性のある地震を想定し，摇れの強さ，液状化の発生，津波の高 さなどの自然現象から，建物，火災，ライフライン，交通，人的被害などに至るまで，どのような被害がどの くらい生じるのかを予測するものである．このような調査は昭和 40 年ころから各地方公共団体で実施されるよ

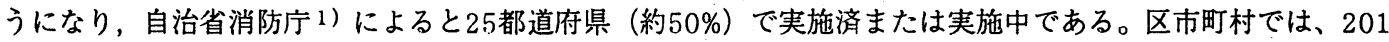
箇所（約6\%）が実施済または実施中であり、都道府県の被害想定を活用している309箇所（約9\%）を合わせる と510箇所（約15\%）となる。なかには，想定地震を変えたり調査時期を変えて見直しをするなど綝返し被害 想定調查を実施している自治体もある。

\section{3. 被害想定調査の問題点と課題}

過去約10年間に発表された15団体17件の被害想定調查（表 1）を対象に、調查期間、前提条件、想定項目、 想定指標、調査方法、想定単位などについて調べた。

表 1 調査した被害想定調査一覧

\begin{tabular}{|c|c|c|c|c|c|c|}
\hline $\begin{array}{l}\text { レベ } \\
\text { ル }\end{array}$ & 番号 & 調査団体 & $\begin{array}{l}\text { 発表 } \\
\text { 年度 }\end{array}$ & 想定地震＊ & 想定 & 備考 \\
\hline 国 & 1 & 国土庁 & 1988 & 海溝 1 & 6 & $\begin{array}{l}1 \text { 都 } 3 \text { 県を対象 } \\
\text { 直下地震は地震動のみ想定 (1993) }\end{array}$ \\
\hline 県 & 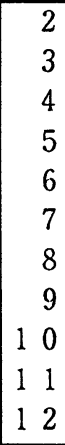 & $\begin{array}{l}\text { 東京都 } \\
\text { 千葉県 } \\
\text { 神奈川県 } \\
\text { 神奈川県 } \\
\text { 埼玉県 } \\
\text { 静岡県 } \\
\text { 愛知県 } \\
\text { 愛知県 } \\
\text { 長野県 } \\
\text { 宮城県 } \\
\text { 福井県 }\end{array}$ & $\begin{array}{l}1992 \\
1985 \\
1986 \\
1993 \\
1991 \\
1994 \\
1991 \\
1995 \\
1987 \\
1988 \\
1989\end{array}$ & 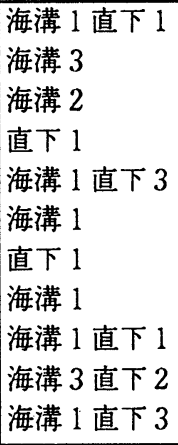 & $\begin{array}{l}6 \\
7 \\
7 \\
7 \\
6 \\
7 \\
7 \\
5 \\
6 \\
7 \\
7\end{array}$ & $\begin{array}{l}\text { 前回（1978,1985）の見直し } \\
\text { 現在、直下も合わせ見直し中 } \\
\text { 神奈川県西部地域のみが対象 } \\
\text { 前回(1982)の見直し+直下地震 } \\
\text { 前回（1989）の見直し } \\
\text { 前回（1979）の見直し } \\
\text { 海溝 } 1 \text { は津波用 } \\
\text { 海溝 } 1 \text { は津波用 }\end{array}$ \\
\hline 市 & $\begin{array}{ll}1 & 3 \\
1 & 4 \\
1 & 5 \\
1 & 6 \\
1 & 7\end{array}$ & $\begin{array}{l}\text { 名古屋市 } \\
\text { 京都市 } \\
\text { 川崎市 } \\
\text { 横浜市 } \\
\text { 横須賀市 }\end{array}$ & $\begin{array}{l}1983 \\
1985 \\
1988 \\
1994 \\
1994\end{array}$ & $\begin{array}{l}\text { 海溝 } 2 \text { 直下 } 1 \\
\text { (なし) } \\
\text { 海溝 } 2 \text { 直下 } 1 \\
\text { 直下 } 1 \\
\text { 海溝 } 2 \text { 直下 } 1\end{array}$ & $\begin{array}{c}7 \\
6 \\
7 \\
500 \mathrm{gal} \\
7\end{array}$ & $\begin{array}{l}\text { その後、被害想定をシステム化 } \\
\text { 地震動のみ } 4 \text { ケース想定 }\end{array}$ \\
\hline
\end{tabular}

* 直下 1 は直下地震 1 ケース、海溝 2 は海溝型地震 2 ケースを示す。 
主な調查結果と問題点を以下に示す。

1 ）調査期間：最低 3 年、なかには 5 年間を要している自治体もある。調査開始時期（データ入手時期）と発 表時期で社会条件などが大きく変化し想定結果に影響をおよはすことも考えられる。

2 ) 想定地震：想定地震は $2 \sim 3$ ケースの場合が多い。以前は被害規模最大地震に着目して想定することが多 かったが、最近は直下地震など局所的な激震の想定調查を開始した自治体がいくつかある。歴史地震の調査か ら想定地震を決める場合がほとんどであるが、地震学研究の現状から考えるとこれだけでは不十分な場合もあ ることから、柔軟に想定地震を決める必要がある。また、市が想定している地震について県レベルでは想定し ていないケースもあるが、広域応援を必要とする地震の場合両者で協力した調査が必要である。

3 ）前提条件：火炎想定の最悪ケースとして「冬の夕方」を前提にしている調査が多い。東京都、静岡県など 何度も調查を実施している自治体が1ケースの前提で想定しており、むしろ市や地方都市が幾ケースかの前提 条件で予測している。火災に限らず、季節、時間帯などにより被害モードが異なる想定項目（人的被害、斜面 崩壊など）があり、被害量全体の大小に加え被害要因別被害量を捕らえる必要から、地域特性を把握した上で 様々な条件での被害想定が望まれる。

4 ）想定項目：首都圈の自治体では想定項目を非常に細かく設定しているが、地方の自治体、市町村では想定 項目が限定されている。地震動、建物、火災、人的被害については全ての調査で想定項目としているが、造成 地被害、塀・落下物被害、道路、ライフライン、危険物などについては対象としていない調査が見受けられる。 また、木造建物は対象としているが、非木造建物を対象としていない調査がいくつかあった。最近注目されて いる屋内収容物の転倒、応急対策上の拠点となる公共建築物を被害想定の対象としている自治体は少ない。

5 ）想定指標：調查によって同じ想定項目でも想定指標が異なる場合がある。木造建築物については「全壊・ 半壊」「大破・中破」「倒壊」などが使われている。ライフラインについては、被害箇所数のみを想定し機能 支障・応急復旧を想定していない調査があるが、応急対策や住民の啓蒙への活用がしにくい。道路については 主要道路の導通確率などを求めている例があるが、このままでは応急対策に反映するのがむつかしい。また、 人的被害については被害要因別に死傷者を想定していないケースがかなりある。以上、対策面から必要で使い やすい想定指標を検討する必要がある。

6 ) 想定単位：メッシュ単位（250m〜1kmメッシュ）または町丁目（町、大字など）単位を用いるのが一般的 である。市レベルでは町丁目など行政単位を利用しているところが多く、概ね対策へ利用しやすいように単位 が決められている。ただし、対策上変化の激しいまたは重要な地域はきめ細かく想定する、また県の結果を市 が利用しやすい単位で提供するなど工夫の余地がある。想定項目ごとに対策への活用、想定精度を吟味した上 で、自治体レベル、想定項目にあった想定単位（メッシュ、町丁目、地点別など）の設定が望まれる。

7 ）調査方法：想定項目によって、複雑な理論計算・シミュレーション（地震動、火災延焼、建物の応答解析 など）と簡便な回帰式（死傷者、ライフライン物的被害など）を用いるものに分かれる。事前想定では、仮定・ 条件パラメータが非常に多いことから、複雑なシミュレーションなど学術研究的な方法よりも簡便な方法でお おざっぱな量が想定できる手法を用いる（開発する）ことが望ましい。また、既往地震被害デー夕を用いて作 られた推定式のなかには、最近の地震で明らかになった知見を考慮していないものもあり、推定式の見直しが 必要である。

以上の他に、筆者がいくつかの想定調査に関わったなかから得られた問題点を合わせて課題とともに表 2 に まとめた。

\section{4. 利用面から見た問題点と課題}

被害想定調査は主に応急対策と住民啓蒙に資する目的で実施されている。応急対策への利用状況を見るため に、応急対策項目と被害想定項目の関係、想定結果の利用例を調へた。東京都の地域防災計画を参考に、応急 対策計画の例と被害想定項目の関係を表 3 に示した。表 3 に示した以外にも、消防・危険物対策、水防・津波 対策、整備·交通規制、緊急輸送、清掃・防疫·死体処理計画、教育·金融·労務対策、ライフラインの応急 対策、公共施設等の応急対策など多くの応急対策計画がある。

また、東京都、足立区、世田谷区、愛知県、名古屋市などの地域防災計画から想定結果の利用状況を調べた。 全ての防災計画において被害想定結果を揭載し対策の前提としているようたが、数値を具体的な対策策定に利 用している項目としては、1）「災害救助用物資の備蓄量」を決めるために「想定被災者数」を用いる、2）

「ごみ処理計画策定」のために「建物被害数」を利用するなどに限られている。一方、「応急給水量の確保」

「避難所の収容人数」など、想定数值ではなく別の指標を利用している項目もある。このように、地域防災計 画と関係する想定項目は多数あるが、利用されている想定項目は少ないようである。理由としては、1）数值 の信頼性などを考慮して他の指標を用いている、2) 想定結果の指標が活用しにくいなどが考えられる。調查 を実施する前に、対策と被害想定の関係を表 3 に示したような形式で検討し、対策に利用しやすい調査項目、 調查指標、調查単位を事前に検討しておく事が重要である。また、県・市の応急対策、被害想定に対する役割 分担も明らかにしておく必要がある。 
表 2 被害想定調查の問題点と課題

\begin{tabular}{|c|c|c|}
\hline 項目 & 問題点 & 課題 \\
\hline $\begin{array}{l}\text { 調查計画と } \\
\text { 調查の実施 }\end{array}$ & $\begin{array}{l}\cdot \text { 調查期間が長い（3～5年）。 } \\
\cdot \text { 調査費用が高額（数千万一数億円）。 } \\
\text { ・市町村によっては独自調査が困難。 }\end{array}$ & $\begin{array}{l}\text { ·調査方法のマニュアル化、システム化。 } \\
\text { ·簡便な想定手法の開発。 } \\
\text { ・自治体間の技術の交換、協力体制。 }\end{array}$ \\
\hline 調査範囲 & ·想定範囲を自治体境界内に限定。 & $\begin{array}{l}\text { ・地震のタイプ、想定項目（道路など） } \\
\text { によては隣自治体との調査協力。 }\end{array}$ \\
\hline 想定項目 & $\begin{array}{l}\text { ·定量化想定項目およびその想定指標が粎々。 } \\
\text { ·想定項目の不足、または除外。 } \\
\text { ·調查項目ごとの被害量推定のみでは、被害の全容が } \\
\text { 見えない。 }\end{array}$ & $\begin{array}{l}\text { ·対策に利用できる項目、指標の整理。 } \\
\text { ・自治体レベルごとの調査分担の明確化 } \\
\text { ·被害シナリオの作成。 }\end{array}$ \\
\hline 前提条件 & $\begin{array}{l}\cdot 1 \text { 数個の特定地震（震源モデル）の想定。 } \\
\cdot \text { 前提条件 (季節、時間带、風速等)が限られている。 }\end{array}$ & $\begin{array}{l}\text { ・前提条件を被害との関係を十分に検討 } \\
\text { して選択する。 } \\
\text { ・システム化。 }\end{array}$ \\
\hline 想定単位 & $\begin{array}{l}\text { •市町村が県想定を参考にする際、利用しやすい想定 } \\
\text { 単位（種類、大きさ）になっていない場合がある。 }\end{array}$ & $\begin{array}{l}\text { ・自治体レベルにあった、対策に使いゃ } \\
\text { すい想定単位の検討。 }\end{array}$ \\
\hline 調査方法 & $\begin{array}{l}\text { ·調査項目によって複雑な方法と簡便な方法の差が激 } \\
\text { しい。 } \\
\text { ·定量化手法がない、被害が極端に少ないなどの理由 } \\
\text { で被害を想定しない場合がある。 } \\
\text { ・最近の地震被害の知見が考虑されてていない。 }\end{array}$ & $\begin{array}{l}\text { ·自治体レベル、調査の精度、対策への } \\
\text { 利用を踏まえた調査方法の検討。 } \\
\text { ・シナリオ作成。 } \\
\text { ・被害算定式の見直し。 }\end{array}$ \\
\hline $\begin{array}{l}\text { 基礎データ } \\
\text { の収集 }\end{array}$ & $\begin{array}{l}\text { ·基礎データの収集に多大な時間・労力がかかる。 } \\
\text { ·必要な基碟調査データがない、また古い場合がある。 }\end{array}$ & $\begin{array}{l}\text { ·他調査との連携。 } \\
\text { •必要なデータを定期的に収集するしく } \\
\text { み。データベース化。 }\end{array}$ \\
\hline 調査結果 & $\begin{array}{l}\text { ·被害量の想定精度が不明確。 } \\
\text { ・経年変化、対策による効果が不明。 } \\
\text { ·隣自治体、上位自治体、前回調查との調査結果が不 } \\
\text { 適合。 }\end{array}$ & $\begin{array}{l}\cdot \text { ·想定手法の検証、想定精度にあった想 } \\
\text { 定結果表示、解釈。 } \\
\text { •対策効果がわかる想定手法の導入。 } \\
\text { ·自治体どおしで連携した調査。 }\end{array}$ \\
\hline その他 & ·類似調查（例：地域危険度調査）の存在。 & ・部局間の調整および調査の統合。 \\
\hline
\end{tabular}

表 3 応急対策項目（地域防災計画）の例と想定項目の関係

\begin{tabular}{|c|c|c|}
\hline 応急対策項目 & 対策のために必要な想定項目（例） & 関連想定項目（例） \\
\hline 救助・救急 & $\begin{array}{l}\text { 要因別地域別救助者数 } \\
\text { 要治療患者数 }\end{array}$ & 道路被害、交通漇滞、情報連絡、医療機関の被害、活 \\
\hline 医療救護 & $\begin{array}{l}\text { 要因別負傷者数、避難所などでの疾 } \\
\text { 病患者数 }\end{array}$ & $\begin{array}{l}\text { 道路被害、交通渋滞、情報連絡、医療機関の被害、活 } \\
\text { 動可能な医療救護班数など }\end{array}$ \\
\hline 避難 & $\begin{array}{l}\text { 避難者数（住居損失、ライフライン } \\
\text { 支障、危険勧告など） }\end{array}$ & $\begin{array}{l}\text { ライフライン機能支障、住宅の損壊・焼失棟数、崖崩 } \\
\text { れ危険地域、避難所の被害など }\end{array}$ \\
\hline $\begin{array}{l}\text { 飲料水·食料な } \\
\text { ど供給計画 }\end{array}$ & 給水、給食必要者数 & $\begin{array}{l}\text { 道路被害、交通渋滞、ライフライン復旧日数、対策要 } \\
\text { 貝数 }\end{array}$ \\
\hline 応急住宅 & 必要仮設住宅数 & 罹災世帯数、災害弱者罹災者数 \\
\hline
\end{tabular}




\section{5. 今後の被害想定調查の進め方}

被害想定調査の全体フレーム案を図 1 に示す。

（1）県、市が一体化した調査

応急対策は一次的に市の役割であり県は庆域応援の立場を取っている。この観点から、県、市が協力して計 画を立て被害想定調查の役割分担を明確にすることが必要である。また、防災对策上市の役割は大きいが、大 きな市を除いて人員・予算などの面で独自に調査をするのはむつかしい。よって、現在市町村によっては調查 を進めている「防災地域カルテ」などをべースにきめ細かな被害想定をする方法（マニュアル、システム）を 県が作成して市へ提供する。市の大きさとデータベースの整備状況などによりそれぞれ手法を開発しておくこ とが望ましい。調査の淮め方としては、県が一次的な被害想定を県内全域において実施し、その調査結果を補 うために市が詳細な被害想定をする。

（2）シナリオ作成に力点を置く。

従来の被害想定では想定地震を決めた上で自治体内をメッシュで分けて定量化被害想定を進めていく方法が 主であった。たたし、現実に発生する被害は全てが平均的・確率的被害予測が可能なものだけではなく、また 平均・確率で扱うことにより被害の本質が見えなくなる項目もある。このように確率的予測がむつかしいもの については、被害を受けた場合を仮定して被害連鎖、対策への影響などの想定を実施することが適当である。 また、一般的に想定しているその地域の歴史地震（既往地震）が最も早く発生するとは断定できない。1000年 に1度の地震を想定して街の完璧な耐震化を図ることには疑問があるが、応急対策の観点からは最悪ケースを 想定して、"広域応援でいかに乗り越えることができるがを十分に想定しておく必要がある。

（3）被害想定とともに対策想定を実施。 従来の被害想定のほとんどは「定量化 被害想定」のみで調査を終了し、先准的 な県では「被害シナリオ」「応急対応シ ナリオ」の例をつけている。ただし、応 急対策シナリオが带りなく淮むのかにつ いては地域防災計画など後の計画立案に ゆだねられているようである。ただし、 被害と対策が一対一の静的な関係にない のはいうまでもない。対策により被害は 軽減するし、対策如何によっては被害が 拡大することもある。いつまでにどの対 策を施すのか（例えば72時間以内の救助 救出など）目標を明確にして、被害想定 と対策想定（救助隊数、アクセスの方法、 機材の量および保管場所の決定、広域応 援）を合わせて実施することが調査の連 続性、一貫性から重要である。

（4）市のきめ細かな被害想定調查

県レベルの一次的な被害想定を受けて 実施する市レベルの被害想定調查は、市 の大きさ、デー夕整備状況に適した調查 方法を計画・実施する必要がある。地震 動・液状化などの被害想定結果は県の算 定結果をそのまま又はモディファイして 利用し、地域データについては自治体が 所有している土地利用、建物用途、課税 台帳データなどを用いて、街区が見える きめ細かな被害想定をなるべ簡易なア ルゴリズムで実施する。人口数10万人の 市にはGISの被害想定への活用2)も十分 可能である。

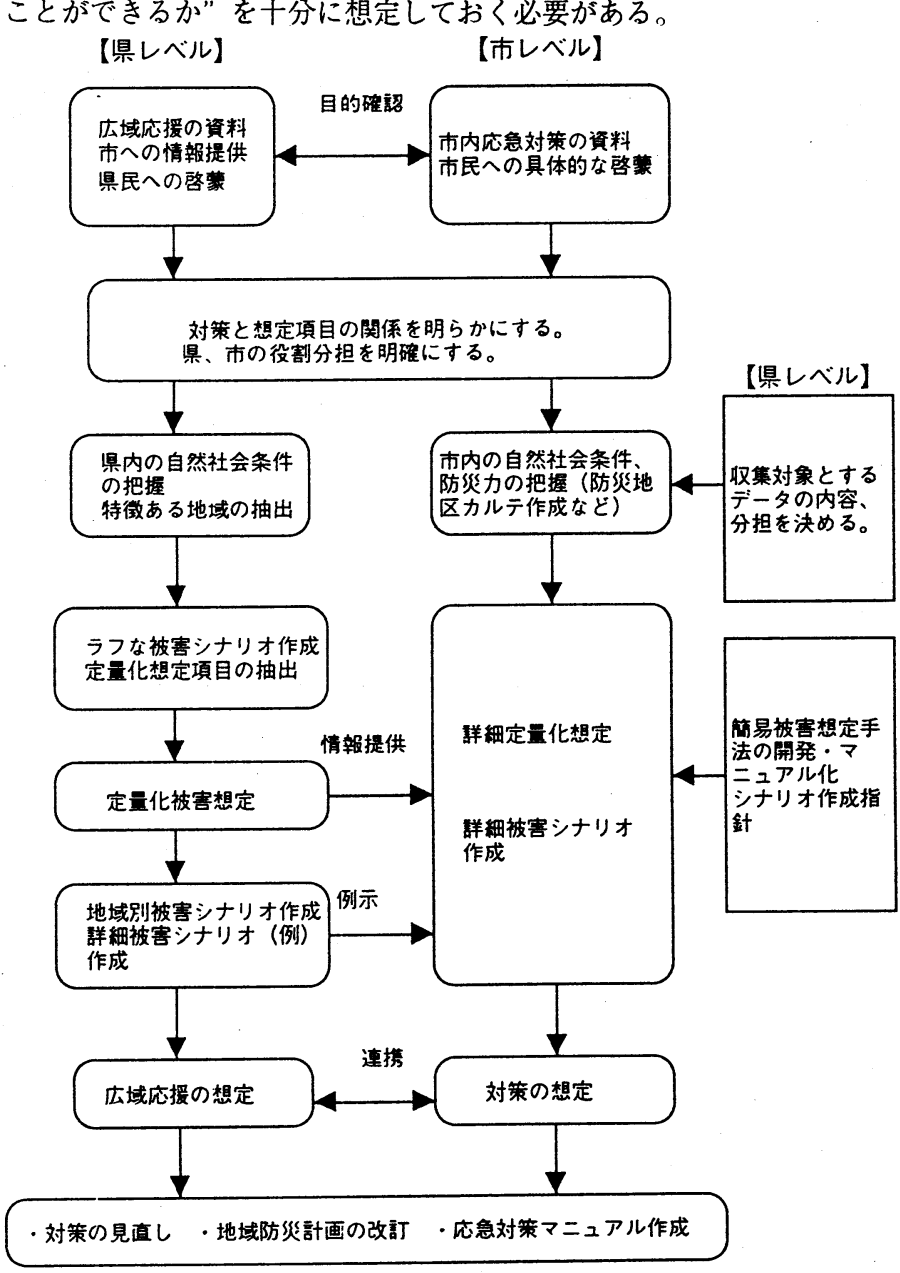

図1被害想定の全体フレーム（寨）

参考文献 1) 自治省消防庁震災対策指導室：震荻対策の現況、1993年12月

2 ）損害保険料率算定会：地域特性を考㙈した地震被害想定に関する研究 $I \sim V 、 1991 １ 995$ 年 $-746-$ 